Arch Virol (1989) 106: 239-259

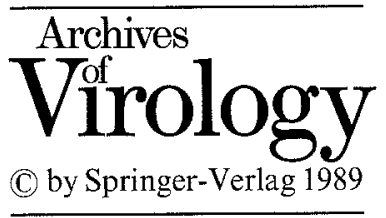

\title{
Intracellular synthesis and processing of the structural glycoproteins of turkey enteric coronavirus
}

\author{
S. Dea ${ }^{1}$, S. Garzon ${ }^{2}$, and P. Tijssen ${ }^{1}$ \\ ${ }^{1}$ Centre de Recherche en Médecine Comparée Université du Québec, \\ Institut Armand-Frappier, Laval-des-Rapides, Québec and \\ ${ }^{2}$ Faculté de Médecine, Université de Montréal, Montréal, Québec, Canada
}

Accepted March 27, 1989

Summary. Pulse labeling of cells with $\left[{ }^{35} \mathrm{~S}\right]$ methionine or $\left[{ }^{3} \mathrm{H}\right]$ glucosamine at different times after infection, followed by SDS-PAGE and Western immunoblotting analysis using rabbit anti-TCV hyperimmune serum, was used to resolve and identify TCV-induced intracellular proteins. The viral structural proteins (gp 200, gp 140/gp66, gp 100/gp 120, p52, and gp 24/p20) were detected in radiolabeled cell extracts by 9 to 12 hours post-infection, as well as two possible non-structural proteins with apparent mol.wts. of 36,000 and 32,000. The predominant 52,000 nucleocapsid protein could be detected in cell lysates as soon as 6 to 8 hours after infection; it was initially resolved as a complex of 3 closely migrating species with mol.wts. ranging from 46,000 to 52,000 . Pulse-chase and immunoprecipitation experiments indicated that $\mathrm{gp} 200$ arose from a putative precursor with mol.wt. of 150,000 to 170,000 , that underwent glycosylation. Proteolytic cleavage of gp 200, in turn, probably yielded the gp 100 and gp 120 species. The unique TCV hemagglutinin protein originated from a primary precursor with mol.wt. of 60,000 , which underwent rapid dimerization by disulfide bond formation and glycosylation to yield gp 140 . The peplomeric and matrix proteins were both shown to be $\mathrm{N}$-glycosylated, as indicated by their sensitivity to tunicamycin (TM) and their resistance to sodium monensin (SM). In the presence of TM, proteins with mol.wts. of 90,000, 120-130,000, and 150,000 accumulated in TCV-infected cells rather than peplomeric glycoproteins, and the matrix protein E1 was only detected in its unglycosylated form. The addition of TM to the culture medium interfered with the maturation of progeny viral particles, as suggested by the absence of peplomers at the surface of the intravacuolar and extracellular virions, and the accumulation of amorphous material not found in the absence of the glycosylation inhibitor. High yields of virus replication were obtained, in the presence of SM, even at concentrations which greatly affected the cellular functions. 


\section{Introduction}

The coronavirus virion possesses two or three major envelope glycoproteins [40]. The latter are synthesized from different virus-specific subgenomic RNAs which are translated at the level of membrane-bound ribosomes [34, 35], and then undergo post-translational processing at the level of rough endoplasmic reticulum or Golgi apparatus $[40,42]$. The peplomeric $(\mathrm{E} 2)$ protein precursors of mouse hepatitis (MHV) and avian infectious bronchitis (IBV) viruses are cotranslationally $\mathrm{N}$-glycosylated and have then an apparent mol.wt. of 150,000 $[27,32,36]$. The polypeptides synthesized in vitro or in tunicamycin-treated cells have a mol.wt. of approximately $120,000[3,28,33]$. This agrees with the mol.wts. of the polypeptide moieties predicted from nucleotide sequences of their E2 genes [1, 20, 31]. A glycoprotein with a mol.wt. of approximately 170,000 has been identified as the intracellular precursor of the E2 protein of bovine enteric coronavirus (BCV), and hemagglutinating mammalian coronavirus $[9,10]$. Unglycosylated precursors have not been yet identified for $\mathrm{BCV}$, but concomitant with the loss of its surface projections, the virus is neither infectious nor hemagglutinating, after cultivation in the presence of TM [10]. Following further glycosylation, the peplomeric protein of these coronaviruses undergoes proteolytic cleavage to yield two subunits with mol.wts. of 85-100,000 $[9,20,41]$. This proteolytic cleavage is a host-cell dependent event and is required for activation of the cell-fusing activity, and therefore appears to be an important determinant of viral pathogenesis [12]. The precursor proteins to the BCV hemagglutinating protein (gp 124/gp 62) are gp 59 (monomer) and gp 118 (disulfide-linked dimer) [9, 10].

The N-terminal regions of the matrix E1 proteins of $\mathrm{MHV}$ and $\mathrm{BCV}$ bear oligosaccharides chains that lack mannose and fucose, and are O-linked to serine or threonine residues, an unusual feature among viral glycoproteins $[18$, $22,27]$. Therefore, the glycosylation process of the p20-23 intracellular precursors does not depend on transfer of oligosaccharides from dolichol phosphate intermediates and is not inhibited by tunicamycin, but by sodium monensin, an inhibitor of the Golgi function $[18,27]$. The matrix glycoprotein of the avian infectious bronchitis virus (IBV) and the porcine transmissible gastroenteritis virus (TGEV), unlike that of $\mathrm{MHV}$ and BCV, has N-linked complex oligosaccharides like those found on the peplomeric glycoproteins $[3,19,37]$. Indeed, two potential $\mathrm{N}$-glycosylated sites are available near the $\mathrm{N}$-terminus of the sequence of the $E 1$ gene of both viruses $[2,19]$. The significance of this diversity of glycosylation patterns among coronaviruses is not known.

Turkey enteric coronavirus (TCV), a major etiological agent of epidemic diarrhea in turkey poults $[5,25]$, possesses an hemagglutinating activity, surface projections of two different types, and biochemical characteristics that resemble those of mammalian hemagglutinating coronaviruses $[4,6,17,19]$. TCV isolates also can be propagated in HRT-18 cells, an established cell line originated from a human rectal adenocarcinoma $[4,7,15,17]$. In the present study, we have 
investigated the intracellular synthesis and post-translational modifications of virus-coded polypeptides in cultures of HRT-18 infected with TCV in the presence or the absence of glycosylation inhibitors. Putative intracellular glycosylated and unglycosylated precursors have been identified for glycoproteins associated with both types of surface projections, and the matrix protein of TCV was found to be glycosylated by a process which was sensitive to tunicamycin, but resistant to sodium monensin. The effects of these glycosylation inhibitors on the viral morphogenesis was confirmed by electron microscopy of TCVinfected cells. Glycosylation of the matrix protein was apparently not required for the formation of the TCV virions.

\section{Materials and methods}

\section{Virus and cell cultures}

The Minnesota strain [21] of TCV and virus stocks were obtained and propagated in HRT18 cells, in the presence of trypsin, as previously described [4, 7]. After five successive passages, the virus was cloned twice by the limiting dilution method. Cloned virus was passaged at a multiplicity of infection of 0.1 to 5 TCID 50 per cell.

\section{Antiserum}

The origin of the rabbit anti-TCV hyperimmune serum was described previously [4].

\section{Radioisotopic labeling of intracellular proteins}

To analyse intracellular synthesis of viral polypeptides, HRT-18 cells were infected at a multiplicity of 10 TCID 50/cell. At given times, indicated in Results and figure legends, the maintenance medium was replaced by medium without methionine. After $30 \mathrm{~min}$ of methionine starvation, the cells were pulse-labeled for $30 \mathrm{~min}$ by the addition of $1 \mathrm{ml} /$ flask of methionine-free RPMI containing $50 \mu \mathrm{Ci} / \mathrm{ml}\left[{ }^{35} \mathrm{~S}\right]$ methionine. Replicate cultures were chased for 1 hour by replacing pulse-medium with complete RPMI containing 5\% FBS and then harvested in ice-cold PBS. In experiments where tunicamycin $(0.01$ to $10.0 \mu \mathrm{g} /$ $\mathrm{ml})$ or sodium monensin $(0.5$ to $5 \mu \mathrm{M})$ was used, the inhibitor was added at the beginning of the starvation period and was present throughout the rest of the experiment.

For pulse-chase labeling of intracellular polypeptides, the infected cells were starved for methionine for $30 \mathrm{~min}$ and then labeled by adding $50 \mu \mathrm{Ci} / \mathrm{ml}$ of $\left[{ }^{35} \mathrm{~S}\right]$ methionine to methionine-free medium, beginning at 6 to 9 hours p.i. for different experiments. After a $30 \mathrm{~min}$ pulse period, the cells were rinsed twice in complete RPMI and then further incubated with this medium for $15 \mathrm{~min}$ to $4 \mathrm{~h}$ before harvesting. The cell sheets were rinsed twice in PBS, and scraped into ice-cold lysis buffer (RIPA) made of $20 \mathrm{mM}$ Tris- $\mathrm{HCl}, \mathrm{pH} 6.8,150 \mathrm{mM}$ $\mathrm{NaCl}, 1 \mathrm{mM}$ EDTA, $0.6 \mathrm{M} \mathrm{KCl}, 0.5 \mathrm{mM} \mathrm{MgCl} 2,1 \%$ Triton X-100, 0.1\% SDS, $1 \% \mathrm{NP} 40$, $10^{3}$ units aprotinin $/ \mathrm{ml}$ and $200 \mu \mathrm{g} \mathrm{PMSF} / \mathrm{ml}$. The cell lysate was immediately passed 10 times through a 26 -Gauge syringe needle, heated to $100^{\circ} \mathrm{C}$ for $3 \mathrm{~min}$, clarified by centrifugation at $15,000 \times \mathrm{g}$ for $20 \mathrm{~min}$, and stored at $-70^{\circ} \mathrm{C}$. Uninfected HRT-18 cells were similarly radiolabeled, and mock lysates were prepared as control samples.

\section{Immunoprecipitation}

The immunoprecipitation assays were performed according to Deregt et al. [9]. Briefly, samples of 50 to $100 \mu \mathrm{l}$ of clarified radiolabeled cytosol extracts $\left(1 \times 10^{6}\right.$ c.p.m. $)$ were mixed with the anti-TCV serum bound to protein A-Sepharose and incubated for $2 \mathrm{~h}$ at $37^{\circ} \mathrm{C}$ 
under gentle agitation. Bound immune complexes were washed three times in RIPA buffer and twice in TBS. Immune complexes were denaturated prior to electrophoresis by boiling for $3 \mathrm{~min}$ in electrophoresis sample buffer.

\section{Western immunoblotting}

Replicas were prepared by electrophoresis transfer of proteins separated by SDS-PAGE to nitrocellulose sheets $(0.45 \mu \mathrm{m}$ pore size, Schleicher et Schüll) as previously described [6]. After saturation with bovine serum albumin (grade V), the nitrocellulose sheets were incubated for $2 \mathrm{~h}$ at room temperature in rabbit hyperimmune sera diluted 1:500 in TBS with $0.05 \%(\mathrm{~V} / \mathrm{V})$ Tween 20 (TBS-T). The nitrocellulose sheets were subsequently washed 3 times for $10 \mathrm{~min}$ in TBS-T, and then incubated with $1: 1000$ dilution of peroxidase-labeled goat anti-rabbit IgG (Boehringer-Mannheim) in TBS-T for 90 min. After washing, blots were developed by reaction for 30 to $45 \mathrm{~min}$ with $0.05 \%$ 4-chloro-1-naphthol (Sigma) substrate, prepared in TBS containing $20 \%(\mathrm{~V} / \mathrm{V})$ methanol.

\section{Polyacrylamide gel electrophoresis}

Samples were mixed with equal volumes of double strength sample buffer with or without 2-mercaptoethanol, boiled for $3 \mathrm{~min}$, and clarified at $10,000 \times \mathrm{g}$ for $15 \mathrm{~min}$ before electrophoresis in 8.5 or 10 percent SDS-polyacrylamide slab gels, as previously described [6]. High and low molecular weight marker proteins or ${ }^{14} \mathrm{C}$-methylated marker proteins were run on each gel to allow molecular weight estimates of viral proteins. Gels were analyzed by autoradiography or fluorography after "Amplify" (Amersham) treatment. Dried gels were exposed to Kodak X-OMAT RP films at $-70^{\circ} \mathrm{C}$.

\section{Electron microscopy}

EM of infected cells, cultivated in the presence of tunicamycin or sodium monensin, was done by fixation with $2.5 \%$ glutaraldehyde followed by post-fixation with $1 \%$ osmium tetroxide, dehydration in graded ethanol and embedding in Epoxy 512, as previously described [7]. Thin sections were stained with lead-citrate and uranyl acetate [11] and examined on a EM 300 Philips microscope.

\section{Chemicals and isotopes}

Tunicamycin (TM), sodium monensin (SM), phenylmethylsulfonyl fluoride (PMSF), aprotinin were purchased from Boehringer-Mannheim Canada Ltd., Dorval, Quebec. Stock solutions of TM $(2 \mathrm{mg} / \mathrm{ml})$ and sodium monensin $(1,000 \mu \mathrm{M})$ were prepared in dimethylsulfoxide and in methanol, respectively. These inhibitors were also purchased from Calbiochem, La Jolla, CA. Bovine pancreatic trypsin (TPCK treated, 12,300 units $/ \mathrm{mg}$ ) and 4chloro-1-naphthol were purchased from Sigma Chemical Co, St. Louis, MO. Reagents for SDS-PAGE were purchased from BIO-RAD Laboratories, Richmond, CA. Protein A Sepharose CL-4B and molecular weight marker proteins were purchased from Pharmacia, Uppsala, Sweden. L- $\left[{ }^{35} \mathrm{~S}\right]$ methionine $(1,120 \mathrm{Ci} / \mathrm{mmole})$ and a mixture of ${ }^{14} \mathrm{C}$-methylated marker proteins were purchasesd from Amersham Searle Co., Oakville, Ontario. D-[6$\left.{ }^{3} \mathrm{H}\right]$ glucosamine hydrochloride $(25-20 \mathrm{Ci} / \mathrm{mmole})$ was purchased from $\mathrm{ICN}$ Biochemical Canada Ltd, Montreal, Quebec.

\section{Results \\ Intracellular protein synthesis}

Pulse labeling of cells with $\left[{ }^{35} \mathrm{~S}\right]$ methionine at different times after infection, followed by SDS-PAGE was used to resolve and to identify polypeptides designated as specific to TCV-infected HRT-18 cell cultures (Fig. 1A). Late in 
infection, it was possible to detect the synthesis of four major TCV-induced polypeptides with apparent mol.wt. of $140,000,100,000,52,000$, and 24,000 which were not present in mock-infected control cultures (lane M). Up to four or five minor polypeptides were also consistently resolved and migrated with estimated mol.wt. of $200,000,170,000,36-38,000$, and 30-32,000, respectively (Fig. 1A, arrowheads). The 170,000 minor polypeptide was reproducibly resolved as a doublet. The predominant 52,000 nucleoprotein could be detected as soon as 6 to 8 hours post-infection and was initially resolved as a group of 3 closely migrating bands; the two other polypeptides migrated with estimated mol.wt. of 46,000 and 48,000, respectively. By 12 hours, all four major TCVinduced polypeptides were present; they persisted until virus and host cell protein synthesis was reduced due to extensive cytopathic changes (between 48 and 72 hours post-infection). Between 12 and 24 hours, all polypeptides appeared to be synthesized at a relatively constant rate, without any apparent shut-off of host cell protein synthesis. The four major intracellular polypeptide species comigrated with the viral polypeptides (lane V), as well as the 200,000 and the 36-38,000 polypeptide species. The latter co-migrated also with a polypeptide having similar mol.wt. which also was present in mock-infected cells. All these polypeptides, as well as the 2 species that closely migrated with the nucleocapsid protein, were revealed by Western-immunoblotting using the anti-TCV rabbit hyperimmune serum (Fig. 1C). The 30-32,000 polypeptide was not revealed by the antiserum and may represent a non-structural polypeptide.

Under reducing conditions (Fig. 1B), the major 140,000 intracellular polypeptide was not present, but replaced by another major component with mol.wt. of approximately $60-65,000$. The intracellular polypeptide corresponding to the viral matrix protein was usually resolved as a doublet $(22,000$ and 24,000$)$.

\section{Intracellular processing of TCV glycoproteins}

To investigate the intracellular processing of the viral structural proteins, TCVinfected and mock-infected HRT-18 cells were pulse-labeled from 6 to 12 hours after infection for $30 \mathrm{~min}$ with $\left[{ }^{35} \mathrm{~S}\right]$ methionine, and the label was chased for various times. Polypeptides specific to TCV-infected cell cultures were then immunoprecipitated with the rabbit anti-TCV hyperimmune serum, and the precipitates were analyzed by SDS-PAGE. As shown in Fig. 2, pulse-chase experiments conducted at 7 and 8 hours after infection permitted the identification of new immunoprecipitable protein species with mol.wts. of approximately 150,000 to $170,000,120,000,90,000,62,000$, and $22-24,000$. No processing of the major $\mathrm{p} 52$ nucleocapsid protein was apparent during the 4 hourchase period, but significant variation was noted in the intensity of the 200,000, 140,000 , and 100,000 protein bands. The 62,000 mol.wt. species was present during the first hour of the chase period and then disappeared from the gel, concomitant with the appearance of a weak band corresponding to a polypeptide with an approximative mol.wt. of 130,000, which later seemed to be converted 


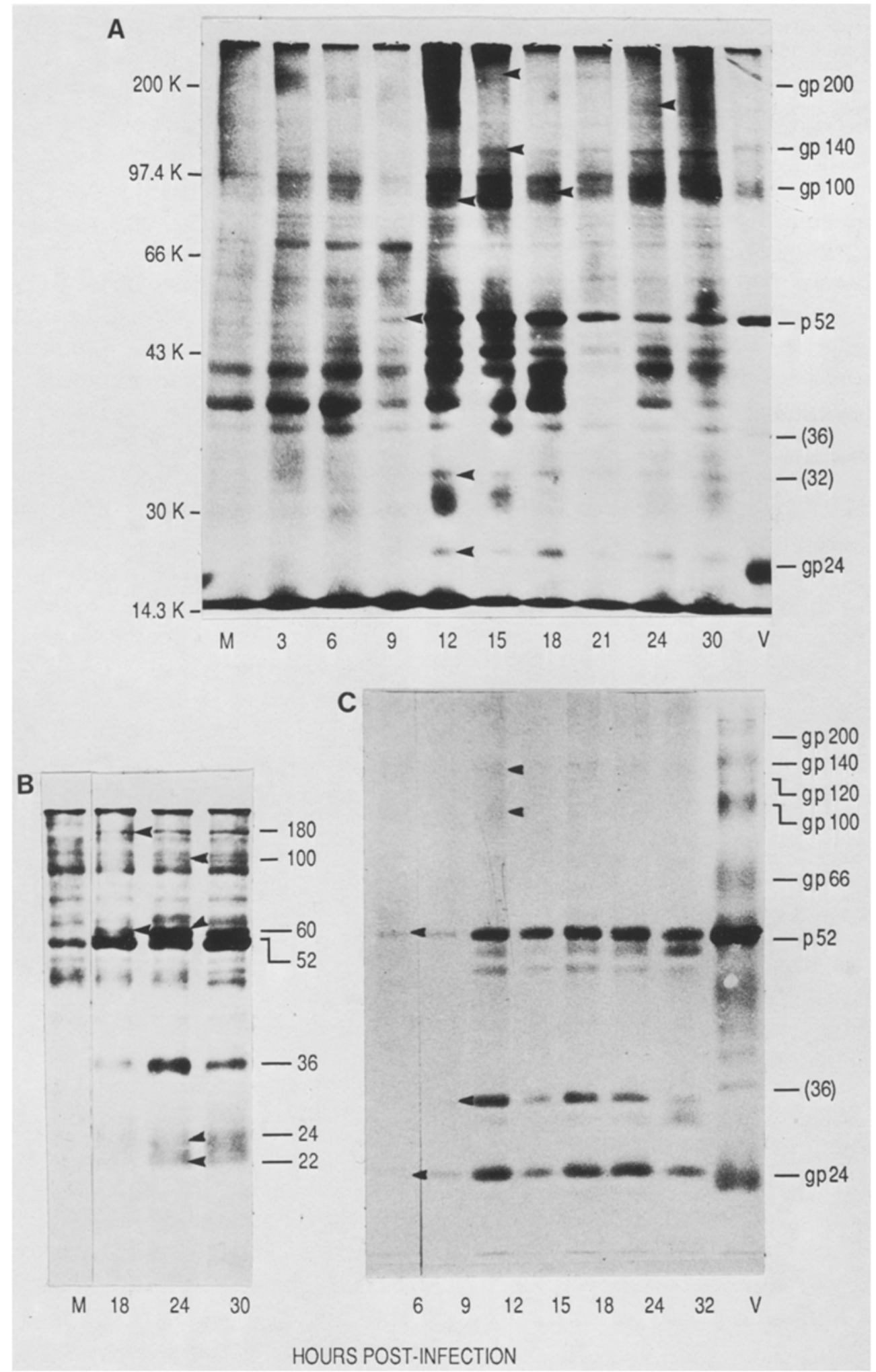


into the gp 140 species. The 90,000 mol.wt. species, present since the beginning of the chase period, was progressively chased to give the final gp 100 species. The 120,000 protein species was also present from the beginning of the chase period and increased in intensity without any apparent change in its electrophoretic mobility. The 150 to 170,000 mol.wt. species was evident after $45 \mathrm{~min}$, and remained detectable until the end of the chase period. The 200,000 protein band intensified as the infection progressed, concomitant with an increase in the intensity of gp 100 and the 120,000 mol.wt. species. The higher mol.wt. polypeptide disappeared later during the infection.

Processing seemed also to occurred among lower mol.wt. proteins. A 36,000 mol.wt. protein, co-migrating with a protein present in mock-infected cell lysates (data not shown), appeared to be chased into a 38,000 mol.wt. species. A minor band of 44,000 also appeared in the gels after the first hour of the chase period. Processing of the small matrix glycoproteins could hardly be demonstrated by immunoprecipitation. However, by SDS-PAGE analysis of cell lysates obtained after various chase periods, an increase in the intensity of the 24,000 protein band was noted concomitant with a decrease in the 20-22,000 protein band, presumably due to the glycosylation of the p20-22 to form the gp 24 (Fig. 2B). The immunoprecipitations of chased lysates with pre-immune serum were all negative, as was the immunoprecipitation of uninfected lysates with the specific hyperimmune serum (data not shown).

\section{Effects of glycosylation inhibitors on TCV-induced intracellular proteins synthesis}

To determine the nature of the glycosidic bonds present on each TCV glycoprotein, infected and mock-infected cells were maintained in media supplemented with either tunicamycin (TM) or sodium monensin (SM) and pulselabeled with $\left[{ }^{35} \mathrm{~S}\right]$ methionine or $\left[{ }^{3} \mathrm{H}\right]$ glucosamine to follow the effects of the inhibitors on synthesis and glycosylation of TCV-induced intracellular proteins.

No cytopathic changes or polycaryocytosis were observed when TCV-infected cell cultures were grown in the presence of 0.5 or $1.0 \mu \mathrm{g} / \mathrm{ml}$ of TM. In contrast, the addition of 0.5 to $2.5 \mu \mathrm{M}$ sodium monensin did not interfere with

Fig. 1. Polypeptides synthesized in TCV-infected cells. A, B Confluent monolayers of HRT18 cells were infected with the fourth cell-culture passage of TCV at a multiplicity of infection of 5 TCID 50/cell and labeled at the time indicated for $30 \mathrm{~min}$ in medium containing $50 \mu \mathrm{Ci} / \mathrm{ml}\left[{ }^{35} \mathrm{~S}\right]$ methionine. Cell lysates were prepared as described in Methods. Samples of each lysate $(100,000 \mathrm{cpm})$ were analyzed by SDS-PAGE in the absence (A) or the presence (B) of 2-ME. The polyacrylamide concentration in the gel was 10 per cent. Positions of molecular weight standards are shown on the left. $M$ Mock infected; $V$ purified virus. $C$ Immunoblots of TCV-infected cell lysates, after separation by SDS-PAGE in the absence of 2-ME, and incubated with rabbit anti-TCV hyperimmune serum. Minor polypeptide species 


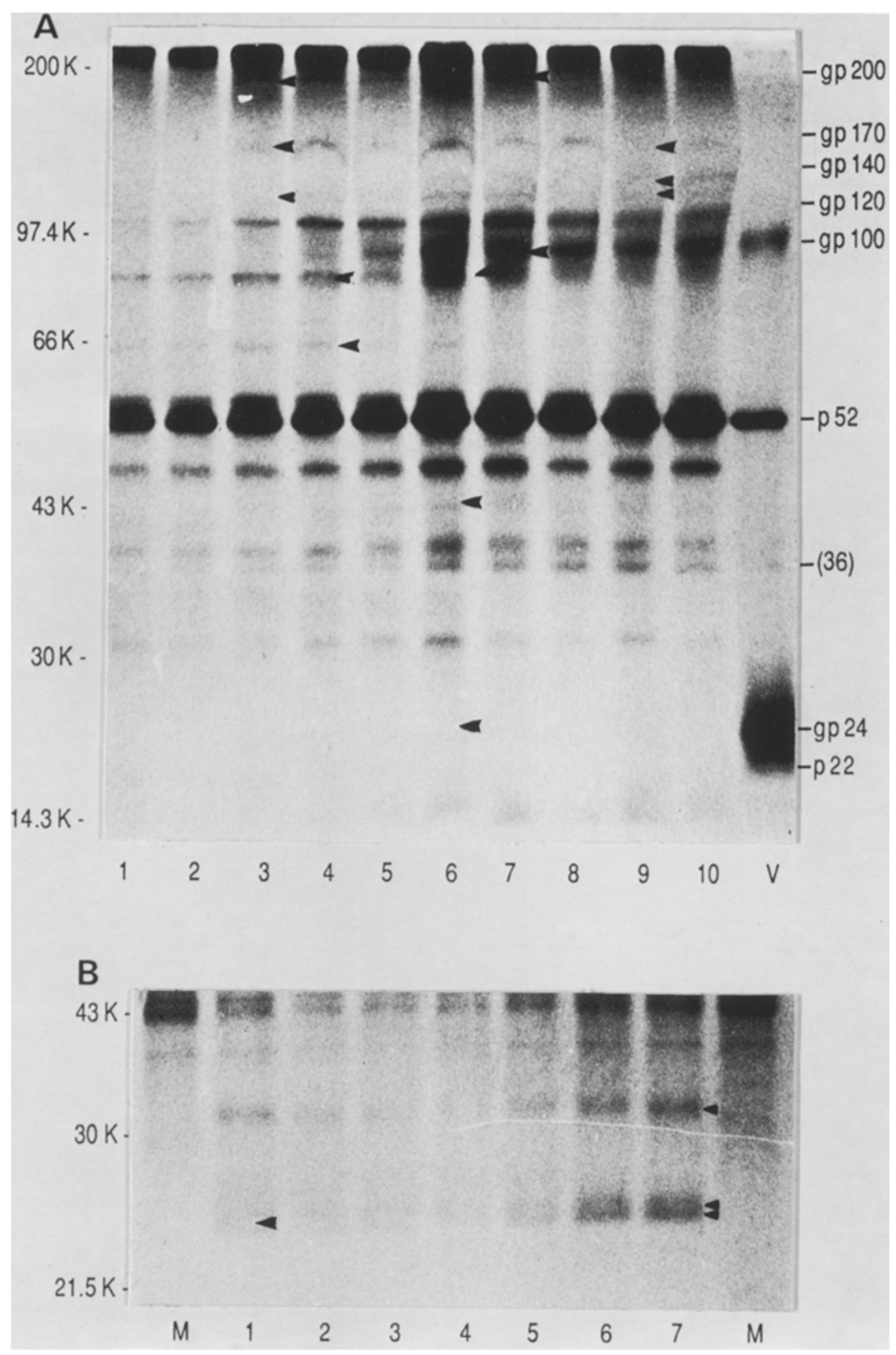

Fig. 2. Intracellular processing of TCV glycoproteins. A TCV-infected HRT-18 cells were pulse-labeled with $\left[{ }^{35} \mathrm{~S}\right]$ methionine for $30 \mathrm{~min}$ at 8 hours after infection and chased in RPMI for various times. Aliquots of clarified cytoplasmic lysates were then immunoprecipitated with the anti-TCV hyperimmune serum. 1-10 Cells that were pulsed and chased for $15 \mathrm{~min}$ (1), $30 \mathrm{~min}(2), 45 \mathrm{~min}(3), 60 \mathrm{~min}(4), 75 \mathrm{~min}(5), 90 \mathrm{~min}(6), 120 \mathrm{~min}(7), 150 \mathrm{~min}(8), 180 \mathrm{~min}$ (9), and $240 \mathrm{~min}(10)$. Proteins were solubilized with electrophoresis sample buffer in the absence of 2-ME. Analysis was done in 10 per cent gels. B SDS-PAGE analysis of cell lysates obtained after chase periods of $15 \mathrm{~min}(2), 30 \mathrm{~min}(3), 60 \mathrm{~min}$ (4), $90 \mathrm{~min}(5), 120 \mathrm{~min}$ (6), and $180 \mathrm{~min}(7)$ showing the processing of the matrix protein. The figure only represents the lower part of the gel after fluorography. $V$ Purified virus (A), $M$ mock infected cell lysates. Positions of molecular weight standards are on the left, polypeptide species which underwent processing 


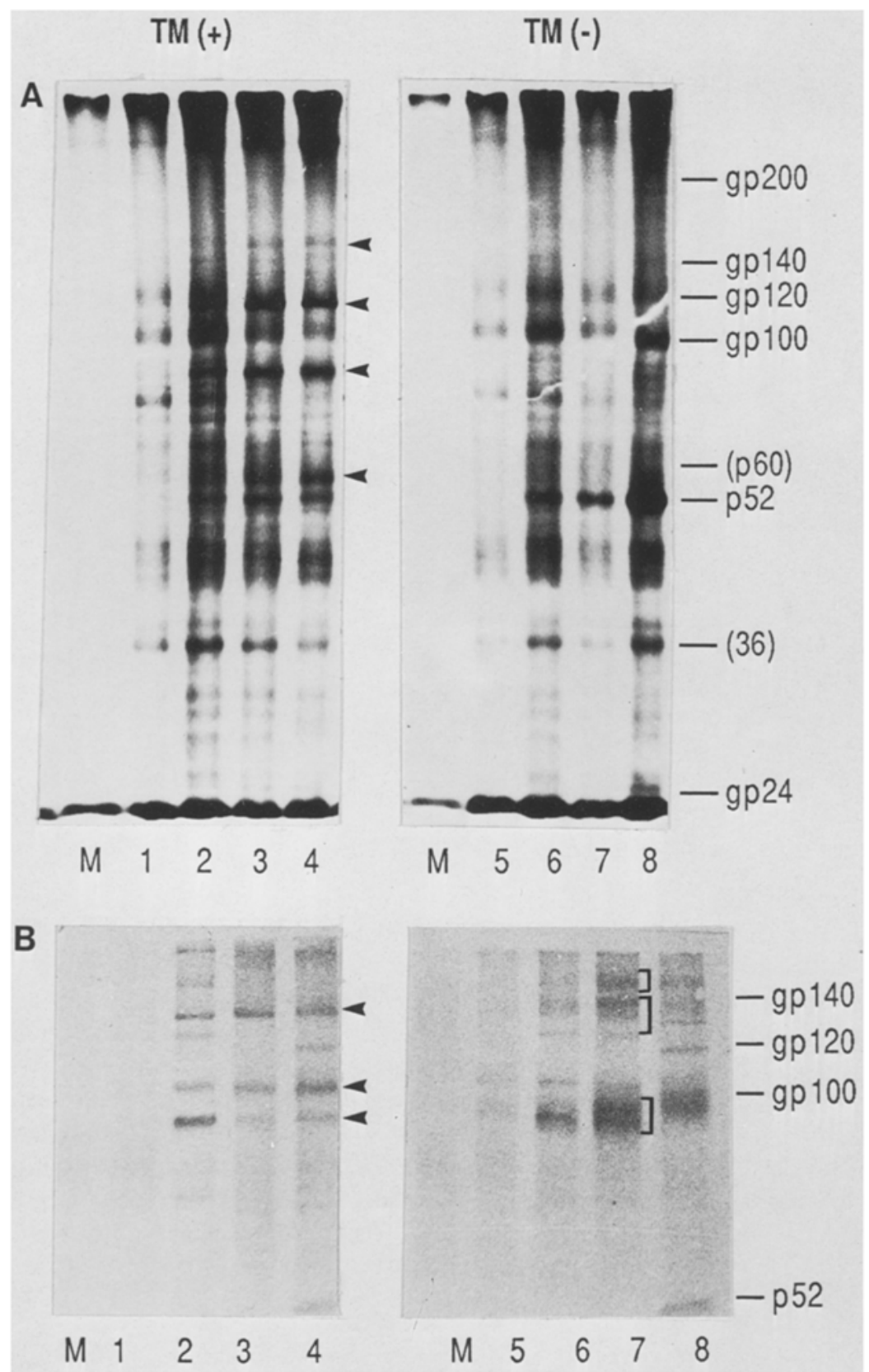

Fig. 3. Effect of tunicamycin (TM) on intracellular viral protein synthesis. A TCV-infected and mock-infected HRT-18 cells were incubated $T M(+)$ in the presence or $T M(-)$ the absence of $0.5 \mu \mathrm{g} / \mathrm{ml} \mathrm{TM}$, and pulse-labeled with $\left[{ }^{35} \mathrm{~S}\right]$ methionine for $30 \mathrm{~min}$ at the time indicated. After a chase period of 1 hour in RPMI medium, cell lysates were prepared and analyzed by fluorography after SDS-PAGE in 10 per cent slab gels. B Immunoblot of the upper part of gel A showing the inhibition by TM of the synthesis of high molecular weight structural glycoproteins of TCV. In the absence of TM, glycoproteins were revealed as diffused bands after incubation with the anti-TCV hyperimmune serum. $M$ Mock infected cell lysates. New intracellular species which appeared in the presence of TM 


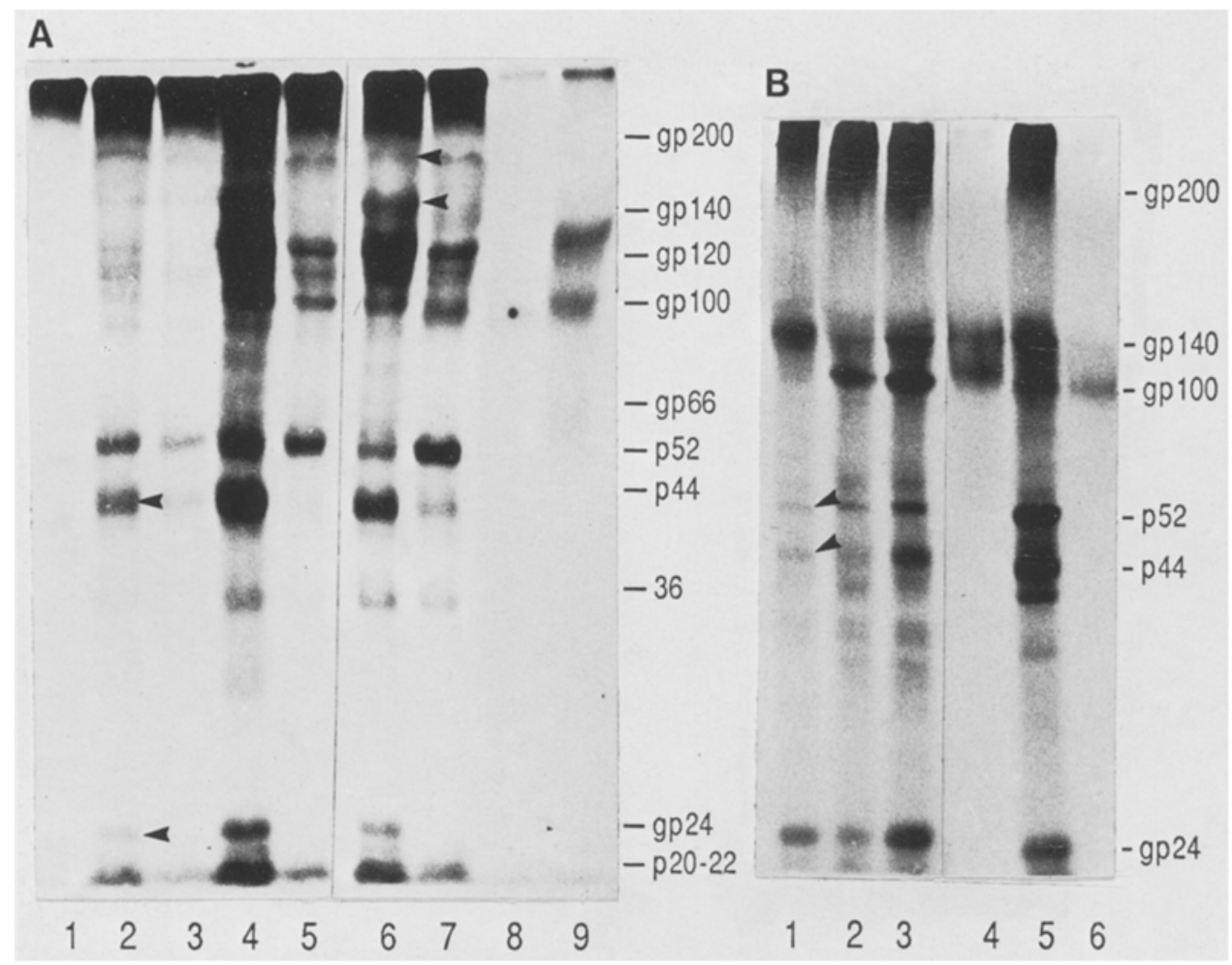

Fig. 4. Effects of tunicamycin (TM) and sodium monensin (SM) on the synthesis and glycosylation of TCV-induced intracellular proteins. A TCV-infected HRT-18 cells were cultivated in the presence of $1.0 \mu \mathrm{M}$ of SM $(1,2,4,6,9)$, or $1.0 \mu \mathrm{g} / \mathrm{ml}$ of TM $(3,5,7,8)$, and pulse-labeled with $\left[{ }^{35} \mathrm{~S}\right]$ methionine $(1-7)$ or $\left[{ }^{3} \mathrm{H}\right]$ glucosamine $(8,9)$ for $30 \mathrm{~min}$ at $6 \mathrm{~h}$ $(1), 9 \mathrm{~h}(2,3), 12 \mathrm{~h}(4,5)$, and $18 \mathrm{~h}(6-9)$ after infection. Following a chase period of 1 hour in RPMI containing the appropriate glycosylation inhibitor, clarified cell lysates were immunoprecipitated with the rabbit anti-TCV hyperimmune serum. Immunoprecipitates were solubilized in sample buffer without 2-ME and analyzed by electrophoresis in 9 per cent SDS-polyacrylamide gels. B Immunoprecipitation profiles obtained with lysates of TCV-infected cells in the absence of the glycosylation inhibitors. Infected cells were pulselabeled with $\left[{ }^{35} \mathrm{~S}\right]$ methionine $(1-3,5)$, or $\left[{ }^{3} \mathrm{H}\right]$ glucosamine $(4,6)$ at $6 \mathrm{~h}(1), 9 \mathrm{~h}(2), 12 \mathrm{~h}(3$, $4)$, and $18 \mathrm{~h}(5,6)$ after infection

the normal course of the viral infection and polykaryocytosis could be demonstrated in the first 24 hours of infection.

Tunicamycin at a concentration of $0.5 \mu \mathrm{g} / \mathrm{ml}$ slightly decreased the overall intracellular protein synthesis, as suggested by the intensity of bands of $\left[{ }^{35} \mathrm{~S}\right]$ methionine-labeled proteins resolved by SDS-PAGE of cell lysates. Polypeptides corresponding to TCV peplomeric glycoproteins showed a drastic decrease in their apparent molecular weights, yielding 90,000, 120-130,000, and 150,000 polypeptide species (Fig. 3A, arrowheads). These new intracellular polypeptides were also resolved by Western immunoblotting (Fig. 3B). Radioim- 
munoprecipitation experiments using the anti-TCV hyperimmune serum, after $\left[{ }^{35} \mathrm{~S}\right]$ methionine and $\left[{ }^{3} \mathrm{H}\right]$ glucosamine labeling, confirmed the absence of the peplomeric glycoproteins from TM-treated cells, whereas the relative amount of the unglycosylated high mol.wt. polypeptide species increased (Fig. 4A, lanes 5 and 7). A major non-glycosylated polypeptide having a mol.wt. of 60,000 was also revealed in the presence of TM.

In contrast, both types of surface glycoproteins (gp 180-200/gp 100 and gp 140) were immunoprecipitated from extracts of SM-treated TCV-infected cells and strongly labeled with $\left[{ }^{3} \mathrm{H}\right]$ glucosamine (Fig. 4A, lane 9). A major polypeptide with an approximate mol.wt. of $150-170,000$ was also immunoprecipitated after treatment with SM, but appeared slightly labeled with $\left[{ }^{3} \mathrm{H}\right]$ glucosamine (Fig. 4A, lanes 4 and 6 ).

Glycosylation of the matrix protein of TCV was also affected by TM. Neither the major gp 24, nor the 36-38,000 and 44,000 mol.wt. species could be immunoprecipitated after TM treatment (Fig. 4A). In contrast, all these protein species were identified in immunoprecipitates from extracts of untreated and SM-treated TCV-infected cells (Fig. 4A, B).

\section{Effects of glycosylation inhibitors on TCV maturation}

The maturation of TCV in the absence or presence of glycosylation inhibitors was followed by sequential analysis by EM of ultrathin sections of TCV-infected cells. Electron microscopic examination of negatively stained untreated TCVinfected cells, at 18 hours after inoculation, revealed budding of coronavirus particles through intracytoplasmic membranes and their accumulation in the lumen of smooth-walled vesicles (Fig. 5A). Progeny viral particles were shown at the outer surface of infected cells, but none have been observed to be budding from the plasma membrane. The intracellular and extracellular viral particles were spherical in shape with an electron-lucent center and possessed large bulbous surface projections (Fig. 5B).

The formation of virions was not inhibited by 0.1 to $1.0 \mu \mathrm{g} / \mathrm{ml}$ of TM (Fig. 6). Complete virions were observed in dilated cytoplasmic vacuoles, but there was also an important accumulation of amorphous material, suggesting at least a partial interference with the viral assembly (Fig. 6A). Virions that were present in the cytoplasmic vacuoles migrating to the cell surface apparently lacked the characteristic large peplomers of coronaviruses (Fig. 6B). The virions were released from TM-treated cells, but usually none were adsorbed to the plasma membrane.

The addition of SM to the medium of TCV-infected cell cultures did not interfere with the normal maturation of the virus (Fig. 7). Large numbers of progeny viral particles could be observed in the cytosol even at a SM concentration of $5 \mu \mathrm{M} / \mathrm{ml}$. However, such high concentration of SM seemed to be very toxic for HRT-18 cells, as suggested by the intensive vacuolisation (Fig. 7B). The viral particles that accumulated in the lumen of smooth-walled vesicles of 

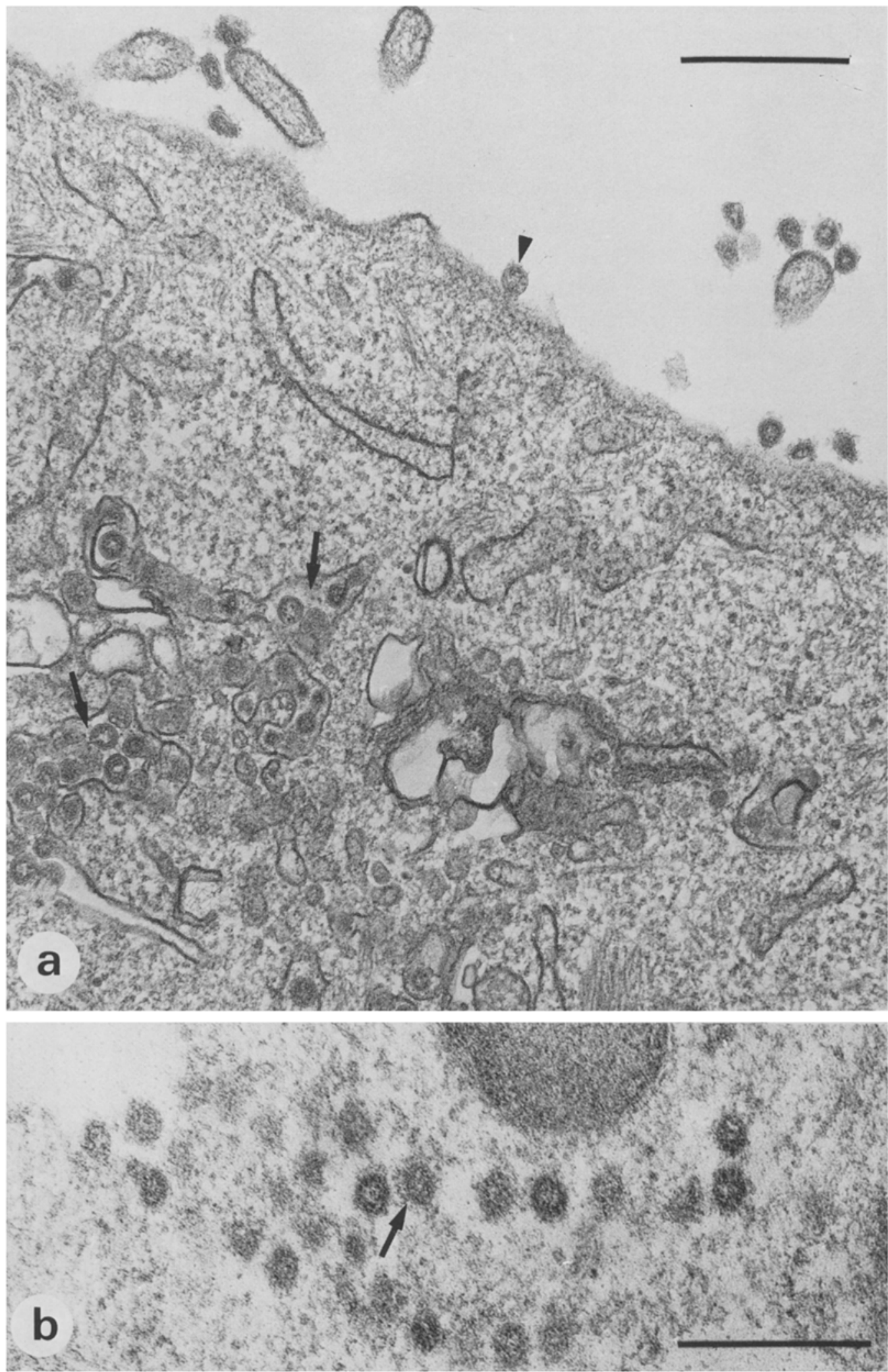

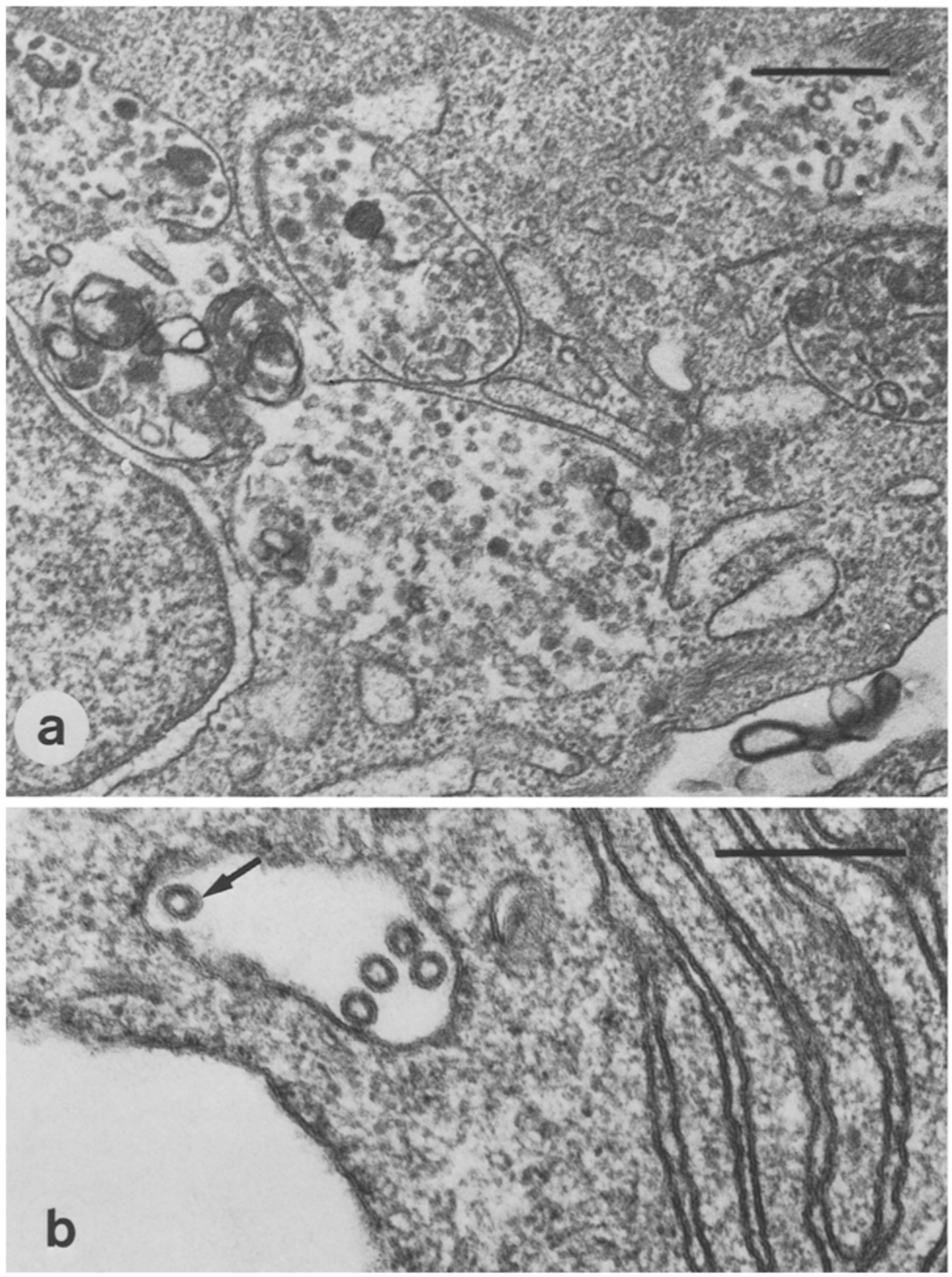

Fig. 6. Effect of tunicamycin (TM) on virus maturation. a Electron micrograph of TCVinfected HRT-18 cells cultivated in the presence of $1.0 \mu \mathrm{g} / \mathrm{ml}$ of TM showing an accumulation of viral particles and amorphous material in smooth-walled vesicles. $\mathbf{b}$ The intracellular progeny viral particles lacked surface projections (arrow) and no virions were observed at the plasma membrane. The bars represent $0.5 \mu \mathrm{m}$

Fig. 5. Electron micrograph of TCV-infected HRT-18 cells. a At $18 \mathrm{~h}$ after infection, large numbers of virions were observed in the lumen of the smooth-walled vesicles (arrows). A few progeny viral particles were observed at the outer surface of the cells $(\boldsymbol{\nabla})$. b Intracellular virions appeared as spherical particles with electron-lucent centers and possessed large bulbous projections (arrows). The bars represent $0.5 \mu \mathrm{m}$ 


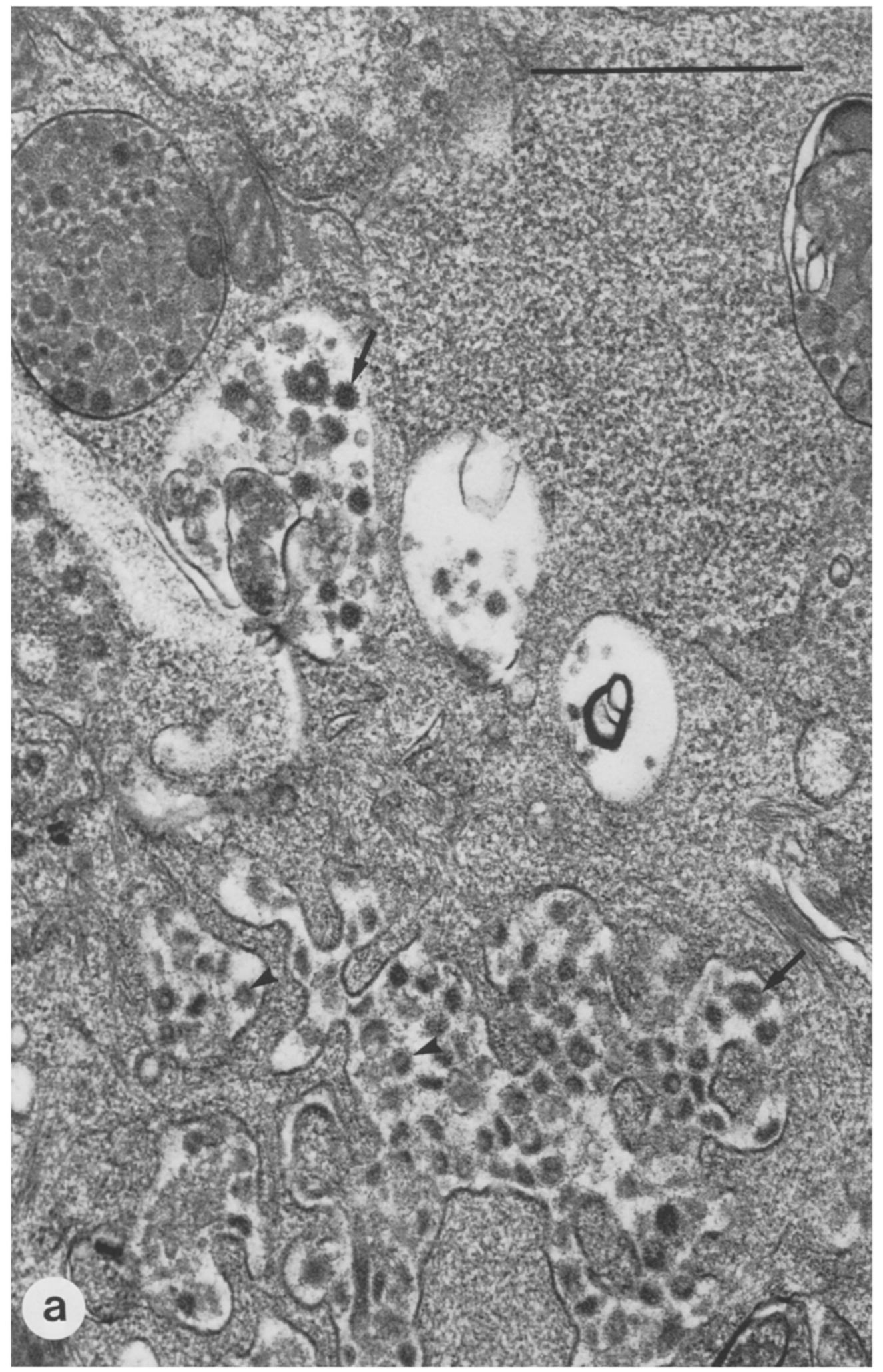




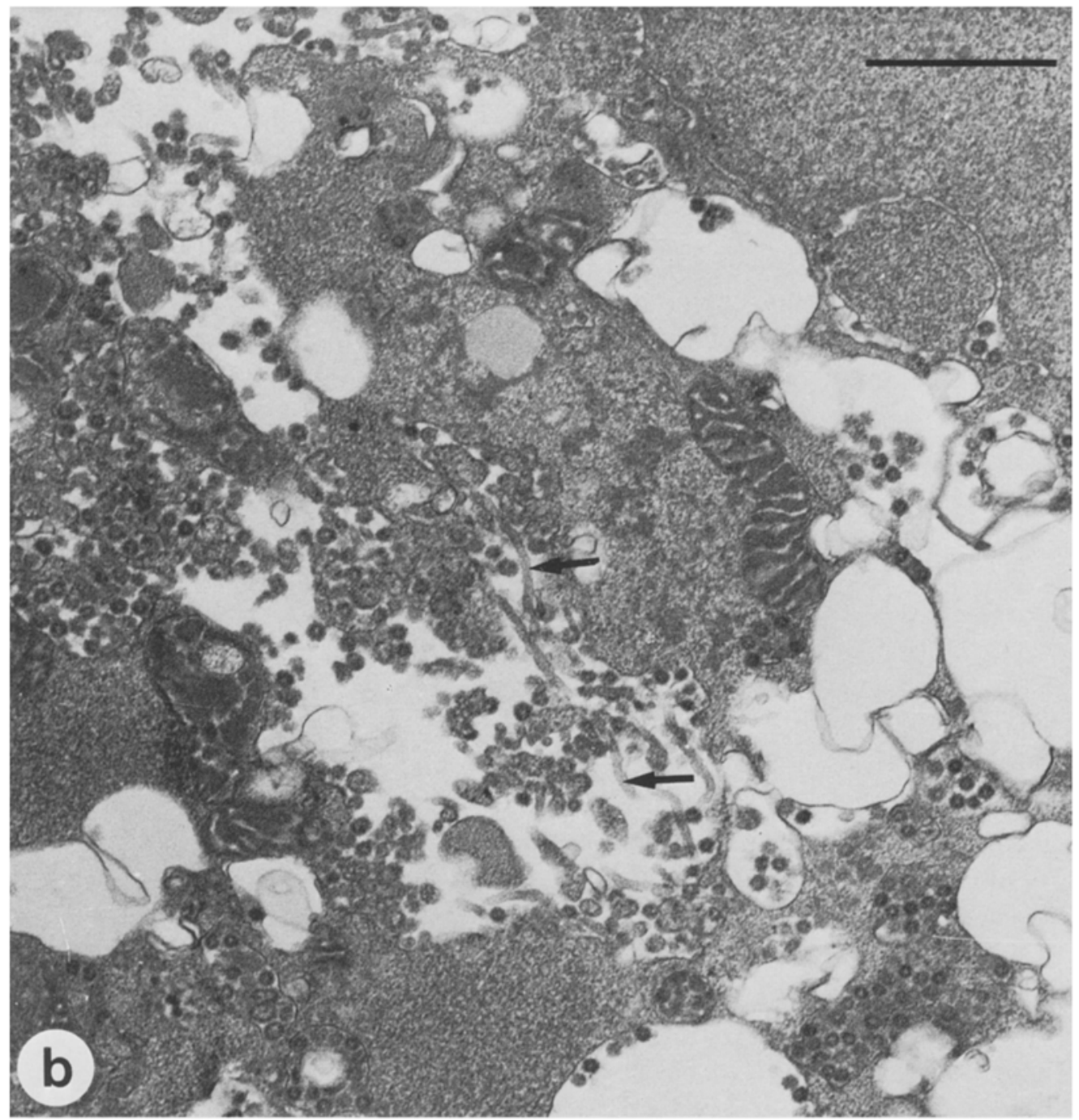

Fig. 7. Effect of sodium monensin (SM) on virus maturation. a Electron microscopy of TCV-infected HRT-18 cells after cultivation in the presence of 1.0 to $2.5 \mu \mathrm{M}$ of SM showed large amounts of progeny viral particles in cytoplasmic vacuoles and intercellular spaces (4). The particles possessed the characteristic surface projections of coronaviruses (arrows). b At an SM concentration of $5 \mu \mathrm{M}$, there was an intense vacuolisation, and large amounts of virions and tubules-like structures (arrows) were observed in the cytosol. The bars represent $1 \mu \mathrm{m}$

cells treated with 1 to $2.5 \mu \mathrm{M} / \mathrm{ml}$ of $\mathrm{SM}$ had a morphology similar to those produced in the absence of the glycosylation inhibitor (Fig. 7A). Numerous viral particles were observed in the intercellular spaces and, many were adsorbed to the plasma membrane. These virions possessed the characteristic surface peplomers. Long tubules, 25 to $30 \mathrm{~nm}$ in diameter, accumulated in dilated cysternae or in cytoplasmic vacuoles (Fig. 7 B). 


\section{Discussion}

Previous studies on the structural proteins of the TCV virions, produced in cell cultures or in ovo, have revealed a polypeptide pattern described so far only for viruses belonging to the subgroup of mammalian hemagglutinating coronaviruses [6]. In addition to the peplomeric and matrix glycoproteins, TCV virions contain an envelope glycoprotein, having a mol.wt. of 140,000 , which behaves as a disulfide-linked dimer of 60-65,000 subunits, and which has been associated to the hemagglutinin (accompanying paper). In this paper, we described the identification of virus-induced intracellular polypeptides in TCV-infected HRT18 cells, the kinetic of their synthesis, their post-translational processing in the presence of glycosylation inhibitors and their significance with respect to the production of mature virions.

We found that TCV had a modest inhibitory effect on cell protein synthesis, making the analysis of virus-specific proteins difficult. Nevertheless, new intracellular protein species could be detected as soon as $6 \mathrm{~h}$ post-infection either by SDS-PAGE analysis of pulse-labeled TCV-infected cell extracts or by Western-immunoblotting, using anti-TCV hyperimmune serum produced to the eggadapted Minnesota strain. The TCV structural proteins were all detected by $9 \mathrm{~h}$ post-infection, in agreement with the one-step growth curve that was determined in a previous study [7] and the replication cycle of coronaviruses [40]. At least 12 to 14 polypeptides immunoprecipitated from lysates of TCVinfected cells. Six of these polypeptides, with approximate mol.wts. of 150 $170,000,130,000,90,000,48,000,46,000$, and $30-32,000$, did not co-migrate with virion proteins. Although a definitive relationship could not be established among these various intracellular polypeptides, pulse-chased experiments and analysis of infected cell extracts after cultivation in the presence of glycosylation inhibitors suggested that some of these products correspond to intracellular precursors, cleavage products or aggregated forms of structural glycoproteins.

No processing of the $\mathrm{p} 52$ nucleocapsid $(\mathrm{N})$ protein was apparent. Two additional virus-specific binding proteins $(48,000$ and 46,000$)$ which migrated slightly ahead of $\mathrm{N}$ were also identified for MHV and IBV [27, 32, 37]. These two species reacted with monospecific anti-N antibody and, in vitro translation studies of the $\mathrm{N}$ gene have shown that they may correspond to degradation products of $\mathrm{N}[26,28,33]$.

The $30-32 \mathrm{~K}$ polypeptide species present in TCV-infected cell lysates is apparently a virus-induced host cell or non-structural protein, as it was not revealed by Western-immunoblotting. A non-structural protein with a similar mol.wt. also has been detected in MHV-A59 infected cel lysates, and a protein with a mol.wt. of 28,000 was also obtained following cell-free translation of the virion genomic RNA $[8,32]$. Since $\mathrm{p} 28$ is a basic protein which is most abundant in infected cells late in infection, it has been suggested that it may be involved in the processing of the genomic or subgenomic RNAs.

Pulse-chased studies also revealed that TCV peplomeric glycoproteins undergo considerable post-translational changes before incorporation into the 
virion. First glycosylation of the primary translation product from the E2 gene may result in the synthesis of the gp 150-170,000 species, and further glycosylation yields gp200. Subsequent proteolytic cleavage of gp 200 to yield gp 120 and gp 100, as demonstrated in the accompanying paper, appeared to occur quite efficiently, as these two species were the predominant species precipitated from TCV-infected cell extracts. This pattern of processing of E2 is similar to the patterns proposed for the $\mathrm{E} 2$ of $\mathrm{BCV}, \mathrm{MHV}$, and IBV $[9,36,40]$. A primary glycosylated precursor with apparent mol.wt. of 170,000 also has been identified for BCV using anti-E2 monoclonal antibodies $[9,10]$.

In case of $\mathrm{TCV}$, proteolytic cleavage of $\mathrm{E} 2$ probably occurs also prior to the final glycosylation step. A 90,000 mol.wt. non-glycosylated polypeptide was revealed by immunoprecipitation prior to the appearance of gp 170 and, was apparently chased to give the TCV virion gp 100 . Whether these two intracellular polypeptides are in fact related remains to be demonstrated. It may be possible that a certain amount of a primary E2 apoprotein is cleaved and then further glycosylated to give the final gp 100-120. A recent study on the intracellular processing of measles virus $\mathrm{F}$ and HA proteins demonstrated that glycosylation was essential to the post-translation proteolytic cleavage to proceed [30]. Similarly, results obtained with coronavirus MHV-A59 have suggested that the proteolytic cleavage of $\mathrm{E} 2$ was a post-translational event that occured only after assembling of the virion and further processing of the E2 protein in the Golgi apparatus $[12,20,27]$. With TCV, gp 100 and gp 120 species were also demonstrated after treatment with monensin, an inhibitor of the Golgi function, suggesting that the first glycosylation acquired in the RER may be sufficient.

The $90 \mathrm{~K}$ protein may also represent a host cell component similar in mol.wt. to a group of resident proteins of the ER identified as putative receptors or carriers involved in the RER-Golgi translocation step [13]. The "glucose-regulated proteins" grp 78 and grp94, for example, have been identified in the lumen of the ER of a large number of different types of mammalian cells [24]. Recently, it has been demonstrated that unassembled or incorrectly assembled HA protein of influenza virus is prevented from leaving ER, being complexed to a cellular protein with approximate mol.wt. of 90,000 resident in the lumen of ER [14]. A host-cell protein with similar mol.wt. also co-precipitated from lysates of measles virus-infected and TM-treated cells [30].

Propolypeptides or primary-translation products with approximate mol.wts. of 127,000 to 146,000 have been predicted from the amino acid sequences determined by sequencing analysis of the genes encoding the E2 of IBV and MHV [1, 20, 31]. Non-glycosylated polypeptides with apparent mol.wts. of $120-130,000$ and 150,000 were immunoprecipitated from extracts of TCV-infected, TM-treated cells. The new intracellular polypeptides were also identified by Western-immunoblotting. Although a definitive precursor-final product relationship was not demonstrated with E2 or E3, the latter were not synthesized in the presence of TM. This was confirmed by radiolabeling with glucosamine and by EM. Both surface glycoproteins of the TCV virions thus possess N- 
linked oligosaccharides. The observation that the nonglycosylated polypeptides were only detected in the presence of this glycosylation inhibitor indicated that glycosylation of the E2 and E3 was initiated at the co-translational level. This is, again, typical for $\mathrm{N}$-glycosidic linkages. The accumulation of amorphous material in the cysternae of TCV-infected, TM-treated cells may result from the rapid degradation of these putative non-glycosylated precursors. Monensin has been shown to produce an intra Golgi blockade of a number of secretory proteins by collapsing the hydrogen ion gradient across cellular membranes [13]. It thus blocks "O" glycosylation, but not N-glycosylation which occurs in the RER. The $100 \mathrm{~K}$ and $140 \mathrm{~K}$ species were heavily labeled with glucosamine in the presence of monensin, which further supported the results obtained with TM.

The unglycosylated 60,000 and 130,000 mol.wt. proteins species immunoprecipitated from extracts of TCV-infected cells, and the virion 62-65,000 and 140,000 mol.wt. glycoproteins appear to be different forms of the same viral protein. The non-glycosylated $\mathrm{p} 60$ may correspond to the precursor protein, which undergoes glycosylation to yield the gp 62-65 species, before rapid dimerization by disulfide bonds to yield gp 130, as suggested by electrophoresis in the presence of 2-ME. A further glycosylation step would result to the final E3 protein, as described for $\mathrm{BCV}[9,10]$.

The fact that E1 was not detected in lysates of methionine labeled TCVinfected, TM-treated cells, is suggestive of a $\mathrm{N}$-linked glycosylation. The absence in the same gel of the 36-42,000 mol.wt. species, probably corresponding to an aggregated form of $\mathrm{E} 1[10,15,38,39]$, and the presence of $\mathrm{E} 1$ in lysates of TCV-infected, SM-treated cells, further supported this notion. In this respect, TCV differs from viruses of the subgroup of mammalian hemagglutinating coronaviruses $[9,18]$, but resembles IBV $[2,3,37]$. Whereas glycosylation of glycoproteins with $\mathrm{N}$-glycosidic linkages is generally initiated at the co-translational level, glycosylation of E1 of TCV appears to be exclusively a posttranslational event. This is suggested by the observation that apoprotein precursor of $\mathrm{E} 1(\mathrm{p} 20)$ was present in TCV-infected cells prior gp 24. For TCV and IBV, E1 therefore constitutes an example of a membrane glycoprotein that is targeted to the ER and is not subsequently directed further along the secretory pathway. As previously reported for IBV and MHV [3, 16, 37], E1 appeared to be the only glycoprotein required for the formation of TCV virions, and its glycosylation is apparently not essential [3,37]. Arrest of virus budding, as demonstrated in MHV-infected cells cultivated in the presence of monensin [23], was not demonstrated in TCV-infected cells in the presence of TM. This strengthens the notion that glycosylation of $\mathrm{E} 1$ is not necessary for virus budding.

\section{Acknowledgements}

The authors would like to acknowledge the technical assistance of $\mathrm{H}$. Strykowski for preparing the specimens for electron microscopy. 
This report was taken in part from a dissertation to be submitted by S. D. to the Department of Virology, Institute Armand-Frappier, University of Quebec, in partial fulfillment of the requirements for the Ph.D. degree. This research was supported in part by grants received the Quebec Federation of Poultry Producers and the Conseil des recherches et services agricoles du Québec, and a Fellowship to S. D. from the Medical Research Council of Canada.

\section{References}

1. Binns MM, Boursnell MEG, Cavanagh D, Pappin DJC, Brown TDK (1985) Cloning and sequencing of the gene encoding the spike protein of the coronavirus IBV. J Gen Virol 66: 719-726

2. Boursnell MEG, Brown TDK, Binns MM (1984) Sequence of the membrane protein gene from avian coronavirus IBV. Virus Res 1: 303-313

3. Cavanagh D (1983) Coronavirus IBV glycopolypeptides: size of their polypeptide moieties and nature of their oligosaccharides. J Gen Virol 64: 1187-1191

4. Dea S, Marsolais G, Beaubien J, Ruppanner R (1986) Coronavirus associated with outbreaks of transmissible enteritis (Bluecomb) of turkeys in Quebec; hemagglutination properties and cell cultivation. Avian Dis $30: 319-326$

5. Dea S, Tijssen P (1988) Viral agents associated with outbreaks of diarrhea in turkey flocks in Quebec. Can J Vet Res 52: 53-57

6. Dea S, Tijssen P (1988) Identification of the structural proteins of turkey enteric coronavirus. Arch Virol 99: 173-186

7. Dea S, Garzon S, Tijssen P (1988) Isolation and trypsin-enhanced propagation of turkey enteric (Bluecomb) coronaviruses in a continuous human rectal tumor (HRT18) cell line. Am J Vet Res (in press)

8. Denison M, Perlman S (1987) Identification of putative gene products in cells infected with murine coronavirus A59. Virology 157: 565-568

9. Deregt D, Sabara M, Babiuk LA (1987) Structural proteins of bovine coronavirus and their intracellular processing. J Gen Virol 68: 2863-2877

10. Deregt D, Babiuk LA (1987) Monoclonal antibodies to bovine coronavirus: characteristics and topographical mapping of neutralizing epitopes on the E2 and E3 glycoproteins. Virology 161: 410-420

11. Fracca JM, Parks VR (1965) A routine technique for double-staining ultra-thin sections using uranyl and lead salts. J Cell Biol 25: 151-161

12. Frana MF, Behnke JN, Sturman LS, Holmes K (1985) Proteolytic cleavage of E2 glycoprotein of murine coronavirus: host-dependent differences in proteolytic cleavage and cell fusion. J Virol 56: 912-920

13. Gebbart AM, Ruddon RW (1986) What regulates secretion of non-stored proteins by eukaryotic cells? Bioessays 4: 213-218

14. Gething MJ, McCammon K, Sambrook J (1986) Expression of wild-type and mutant forms of influenza hemagglutinin: the role of folding in intracellular transport. Cell 46: 939-950

15. Hogue BG, Brian DA (1986) Structural proteins of human respiratory coronavirus OC43. Virus Res 5: 131-144

16. Holmes KV, Doller EW, Sturman LS (1981) Tunicamycin resistant glycosylation of a coronavirus glycoprotein: demonstration of a novel type of viral glycoprotein. Virology 115: 334-344

17. King B, Potts BJ, Brian DA (1985) Bovine coronavirus hemagglutinin protein. Virus Res 2: 53-59

18. Lapps W, Hogue BG, Brian DA (1987) Sequence analysis of the bovine coronavirus nucleocapsid and matrix protein genes. Virology 157: 47-57 
19. Laude H, Rasschaert D, Huet JC (1987) Sequence and N-terminal processing of the transmembrane protein $\mathrm{E} 1$ of the coronavirus transmissible gastroenteritis virus. J Gen Virol 68: 1687-1693

20. Luytjes W, Sturman LS, Bredenbeek PJ, Charite J, Van der Zeijst BAM, Horzinek MC, Spaan WJM (1987) Primary structure of the glycoprotein E2 of coronavirus MHV-A 59 and identification of the trypsin cleavage site. Virology 161: 479-487

21. Naqi SA, Panigrahy B, Hall CF (1975) Purification and concentration of viruses associated with transmissible (coronaviral) enteritis of turkeys (Bluecomb). Am J Vet Res 36: $548-552$

22. Nieman H, Klenk HD (1981) Coronavirus glycoprotein E1, a new type of viral glycoprotein. J Mol Biol 153: 993-1010

23. Nieman H, Boscheck B, Evans D, Rosing M, Tamura T, Klenk HD (1982) Posttranslational glycosylation of coronavirus glycoprotein $\mathrm{E} 1$ : inhibition by monensin. EMBO J 1: 1499-1504

24. Pelham HRB (1986) Speculations on the functions of the major heat-shock and glucoseregulated proteins. Cell 46: 959-961

25. Pomeroy BS (1984) Coronaviral enteritis of turkeys. In: Hostad MS, Barnes HJ, Calnek BW, Reid WM, Yoder HW (eds) Disease of poultry, 8th edn. Iowa State University Press, Ames, pp 553-559

26. Robbins SG, Frana MF, McGowan JJ, Boyle JF, Holmes KV (1986) RNA-binding proteins of coronavirus MHV: detection of monomeric and multimeric $\mathrm{N}$ protein with an RNA overlay-protein blot assay. Virology 150: 402-410

27. Rottier PJM, Horzinek MC, Van der Zeijst BAM (1981) Viral protein synthesis in mouse hepatitis virus strain A59-infected cells: effect of tunicamycin. J Virol 40:350357

28. Rottier PJM, Spaan WJM, Horzinek MC, Van der Zeijst BAM (1981) Translation of three mouse hepatitis virus strain A59 subgenomic RNAs in Xenopus laevis oocytes. J Virol 38: 20-26

29. Rottier PJM, Welling GW, Welling-Wester S, Niesters HGM, Lenstra JA, Van der Zeijst BAM (1986) Predicted membrane topology of the coronavirus protein E1. Biochemistry 25: 1335-1339

30. Sato TA, Kohama T, Sugiura A (1988) Intracellular processing of measles virus fusion protein. Arch Virol 98: 39-50

31. Schmidt I, Skinner M, Siddell S (1987) Nucleotide sequence of the gene encoding the surface projection glycoprotein of coronavirus MHV-JHM. J Gen Virol 68: 47-56

32. Siddell S, Wege H, Barthel A, Ter Meulen V (1981) Coronavirus JHM intracellular protein synthesis. J Gen Virol 53: 145-155

33. Siddell SG (1983) Coronavirus JHM: coding assignments of subgenomic mRNAs. J Gen Virol 64: 113-125

34. Spaan WJM, Rottier PJM, Horzinek MC, Van der Zeijst BAM (1981) Isolation and identification of virus-specific mRNAs in cells infected with mouse hepatitis virus (MHV-A 59). Virology 108: 424-434

35. Stern DF, Kennedy SIT (1980) Coronavirus multiplication strategy. I. Identification and characterization of virus-specific RNA. J Virol 34: 665-674

36. Stern DF, Sefton BM (1982a) Coronavirus proteins: biogenesis of avian infectious bronchitis virus virion proteins. J Virol 44: 794-803

37. Stern DF, Sefton BM (1982b) Coronavirus proteins: structure and function of the oligosaccharides of the avian bronchitis virus glycoproteins. J Virol 44: 804-812

38. Sturman LS, Holmes KV (1977) Characterization of a coronavirus. II. Glycoproteins of the viral envelope: tryptic peptide analysis. Virology 77: 650-660

39. Sturman LS, Holmes KV, Benke J (1980) Isolation of coronavirus envelope glycoproteins and interaction with the viral nucleocapsid. J Virol 33: 449-462 
40. Sturman LS, Holmes KV (1983) The molecular biology of coronaviruses. Adv Virus Res 28: 35-112

41. Sturman LS, Ricard CS, Holmes KV (1985) Proteolytic cleavage of the E2 glycoprotein of murine coronavirus: activation of cell-fusing activity of virions by trypsin and separation of two different $90 \mathrm{~K}$ cleavage fragments. J Virol 56: 904-911

42. Tooze J, Tooze SA (1985) Infection of AtT 20 murine pituitary tumour cells by mouse hepatitis virus strain A59: virus budding is restricted to the Golgi region. Eur J Cell Biol 37: 203-212

Authors' address: P. Tijssen, Centre de Recherche en Médecine Comparée Institut Armand-Frappier, 531, boulevard de Prairies Laval-des-Rapides, Quebec H7V 1B7, Canada.

Received February 2, 1989 